\title{
Effect of concentrate feeding supplementary to rice straw on dry matter intake and growth rate of young Pyar Sein bulls
}

\author{
K.S. Win ${ }^{1 *}$, Y. Aung ${ }^{2}$, Z.T. Kyaw ${ }^{1}$, K.K. Lay ${ }^{2}$ \\ ${ }^{1}$ Livestock Demonstration Farms \& ${ }^{2}$ Department of Animal Science,University of Veterinary Science, Yezin, \\ Nay Pyi Taw, 15013, Myanmar \\ *Corresponding author e-mail: kyawsanwinksw08@gmail.com
}

Journal of Livestock Science (ISSN online 2277-6214) 13: 6-11

Received on 07/10/21; Accepted on 16/12/2021; Published on 8/1/22

doi. 10.33259/JLivestSci.2022.6-11

\begin{abstract}
The aim of this study was to compare the feed intake and growth performance of young Pyar Sein bulls fed on rice straw with two commercial concentrates. The twelve Pyar Sein bulls were grouped into two treatments, treatment 1 was supplemented with commercial concentrate 1 and treatment 2 was commercial concentrate 2. All grouped bulls were given the same quality of rice straw (RS). Both commercial concentrates were offered on a dry matter basis of $1 \%$ live body weight (BW) of bull per day to each group. No significant differences were found between the treatment groups for average body weight gain, average daily gain (ADG), average dry matter intake of RS, average total dry matter intake and average feed conversion efficiency. Structural growths of wither height and rump height of young bulls were not significantly differed between the two commercial concentrates. The two commercial concentrates could be applied in local Pyar Sein bulls fed rice straw without showing different efficiencies in terms of dry matter intake, daily weight gain, feed conversion efficiency and structural growth of body parts.
\end{abstract}

Key words: Pyar Sein bulls; rice straw; concentrate; daily weight gain, feed conversion ratio 


\section{Introduction}

In 2018, global rice production was approximately 770 million tons with China, India and Brazil being the primary producers (FAOSTAT, 2018). For $1 \mathrm{~kg}$ of rice grain harvested an additional $1.5 \mathrm{~kg}$ of rice straw is residue (Lal, 2005), and thus rice straw becomes main roughage source for ruminants in many rice grain producing countries. Myanmar produced rice grain about 25.6 million tons in 2018 (Myanmar Statistical Year Book 2019, CSO). Although rice straw (RS) is abundant and inexpensive, it is typically considered that the primary influencing factors in the utilization of RS as a ruminant feed are related to the low voluntary intake, poor digestibility, high fiber content and insufficiency of essential nutrients (Minson, 1985). RS has very low crude protein (CP) and digestible energy contents (Sommart, 1998), and this insufficient nutrients subjects to decrease voluntary intake for ruminant. The maintenance requirement of $\mathrm{CP}$ for cattle is $7 \%$ of $\mathrm{DM}$ and the voluntary feed intake declines in forages containing less than 7\% CP (National Research Council (NRC), 2000). Therefore, the RS only feeding does not provide enough amounts of digestible protein for normal growth of cattle. Moreover, ruminants fed RS as a sole diet cannot usually gain body weight and sometimes will lose their weight (Moran et al., 1983).

However, supplementing or feeding protein-rich concentrates to poor-quality straws can promote ammonia nitrogen level in the rumen (Fike et al., 1995), increase fermentation of RS fiber by ruminal microbes (Cho et al., 2012) and can improve ruminal RS particle size reduction and passage rates (Win et al., 2021). Voluntary feed intake of poor-quality roughages such as hay or rice straw was increased by accelerated the RS particle clearance or disappearance rate from the rumen when protein-rich concentrates were supplemented (Stoke et al., 1988; Win et al., 2021). For these considerable evidences, many recent studies indicate protein rich feeds such as conventional (McCollum and Glayean, 1985; Ghorbani et al., 2018), non-conventional (Liu et al., 2001; Huyen et al., 2012) or commercial concentrates supplements (Takahira et al., 2011; Dung et al., 2013; Bakshi \& Wadhwa, 2017, Kyawt et al., 2020) could increase digestibility of crop residues and give satisfactory growth performances of ruminants fed basal diet poor quality roughages.

Rapid export demand of Myanmar live cattle (such as Pyar Sein and Shwe Ni) to China, Malaysia, and Thailand markets is currently a large priority for many local economies, but new domestic markets for value-added beef products are developing. In the 2019-2020 fiscal year, the income of exporting live local cattle to neighbouring countries was earned at US\$222.5 million (GNLM, 2020). Therefore, many cattle farmers and buyers in Myanmar desire cattle with greater growth rates and body weight (BW) for increased production, but they must also address the increased accompanying nutritional demands. In spite of a relatively high price for commercial concentrates comparing conventional protein supplements, some complete concentrates are now using and being fed to local and crossbred cattle for quick growing and fattening in private commercial farms. However, there is lack of data concerned with commercial concentrates and rice straw for considering feeding references of cattle production in Myanmar. As mentioned above, there is a quantitative requirement to evaluate the effects of commercial concentrates on feed intake and growing performances of young local bulls fed rice straw during the dry season from January to May.

\section{Materials and Methods}

\section{Animals and experimental feeds}

This feeding trial was carried out from $17^{\text {th }}$ December 2020 to $31^{\text {st }}$ May 2021 . Twelve local young bulls (20-22-month-old, $260.0 \pm 26.75 \mathrm{~kg}$ BW) were reared at Cattle Demonstration Farm, University of Veterinary Science, Yezin, Nay Pyi Taw, latitude $19^{\circ} 50^{\prime} \mathrm{N}$ and longitude $96^{\circ} 15^{\prime} \mathrm{E}$, at an altitude of $599 \mathrm{~m}$ above sea level. All animal-based procedures were approved by Committee of Animal Experiments' Guidelines at University of Veterinary Science, Myanmar. Young bulls were individually weighed and randomly divided into two dietary groups and six bulls of each group were arranged in accordance with Animal Protection and Welfare Standards. Group 1 bulls were fed commercial concentrate 1 and group 2 bulls were commercial concentrate 2 and the basal diet was rice straw. Before the starting of the feeding trial, all bulls were treated for internal and external parasites with NILZASH Bolus as prescribed by the manufacturer (Ashish Life Science-India).

\section{Collection of samples and data}

The basal diet, rice straw used in this feeding trial was obtained from Nay Pyi Taw area and collected during November, 2020. The rice straw consisted of both stems and leaves of the plant after seed grain harvested and purchased directly from the farmers' fields. Commercial concentrates 1 and 2 of two companies were purchased with current market prices from two different feed dealers near University of Veterinary Science during this feeding experiment. The chemical composition of rice straw, commercial concentrate 1 and commercial concentrate 2 used in this experiment are shown in Table1.

The young bulls were fed treatment diets for 165 days (15 days for the adaptation period and 150 days for the data collection period). Water and mineral block licks were accessed openly. Concentrate 
allowance for each bull was $1 \%$ of live body weight (DM basis) daily and was adjusted monthly in accordance with change to the body weight of the bull. Bulls in both groups were given the same quality of rice straw ad libitum (110\% of the previous day's intake) at 07:30 am and 15:30 pm by two equal portions per day. Amount of feed given, and feed remained were recorded daily to calculate feed intake. Daily samples of feeds were collected before the morning feeding and bulked on a weekly basis for chemical analysis. Feed refusals were removed from the feed trough and weighed before offering the morning amounted feed. Feeding troughs were always cleaned before next feeding for the new feed to become fresh, clean, and free from mould or fungus.

The feed and refusal samples were oven dried at $70^{\circ} \mathrm{C}$ for 48 hours for dry matter (DM) determination. Dried feeds were milled to pass through a $1 \mathrm{~mm}$ sieve using a Wiley mill, and stored in plastic bottles for analysis. Nitrogen (N) and ash were determined according to AOAC (1990). The content of organic matter (OM) was calculated by subtracting ash from 100. The crude protein (CP) content was calculated as $\mathrm{N} \times 6.25$.

Weight changes for young bulls were determined directly by using the monitor digital electrical scale equipment with the maximum capacity of $2000-3000 \mathrm{~kg}$ and weighed between 06:00 and 07:00 am prior to morning feeding. It is the most accurate method of weighing young bull or feedlot cattle. The actual weight value in kilogram was directly read on the monitor of electrical weighing indicator when the bull was weighing. After weighing, body measurements of bulls were continuously worked out. When young bulls were measured for wither height and rump height, they had to be standing with the correct posture; their dorsal line and cheek had to make a straight line, and their four hooves had to make a rectangle. Wither height and rump height were measured by measuring stick with the reference Textbook of Field Practices in Bio-resource Production, University of Tsukuba, Japan.

\section{Weight gain, dry matter intake and feed conversion}

Weight gain, dry matter intake (DMI) and feed conversion were measured by one month interval throughout the feed testing period. Weight changes were determined with balance (CAS balance) for bulls every month. DMI was measured by examining feed supply quantities and remains in the morning and in the afternoon every month for 150 days. Feed conversion was calculated by dividing DMI with weight gain during experimental period.

\section{Statistical analysis}

Data on recorded parameters were subjected to Student's t test (Snedecor and Cochran, 1994), using repeated measures, at $5 \%$ probability. Significance was declared at $\mathrm{P}<0.05$.

\section{Results and Discussion}

The chemical compositions of rice straw differed between varieties and growing season, with higher nitrogen and cellulose contents in early-season rice compared to others. The nutritive values of rice straw used in the current feeding trial are within ranges 89-93\% dry matter (DM), 81.1-84.2\% in organic matter (OM) and 2.7-4.96\% in crude protein (CP) for Myanmar rice straw (Soe et al., 2007).

The slow rate of passage of RS is an intrinsic cause of reduced voluntary intake of RS in ruminants. The intake, body weight gain and feed conversion ratio of local young bulls are shown in Table 2. Voluntary dry matter intake (DMI) of RS was not significantly differed between bulls groups fed commercial concentrate $1(\mathrm{CC} 1)$ and commercial concentrate 2 (CC2). Voluntary DMI of RS was equivalent to $1.35 \%$ and $1.36 \%$ of body weight $(\mathrm{BW})$ of young bulls for $\mathrm{CC} 1$ and $\mathrm{CC} 2$, and total DMI for two bulls groups was $2.21 \%$ of $\mathrm{BW}$. Devendra (1997) reported that the maximum intake of RS by ruminants is a range of within 1-1.2\% of BW of cattle. The current feeding trial during dry season and long period agreed that giving protein rich supplements to RS such as oilseeds meals, mulberry leaves and cassava hay increased voluntary DMI of RS (Liu et al., 2001; Huyen et al., 2012; Dung et al. 2013; Win et al., 2021). The possible reasons of increased voluntary DMI of RS caused by protein-rich supplements were an alteration of host nutrient status involved in metabolic regulation of intake (Kempton et al., 1977), an additional protein supply to the host animal or rumen which can lead to a correction or elevation of ammonia for ruminal microbes limiting fiber digestion (McCollum \& Glayean, 1985) and increased ruminal RS particle size reduction, passage and speeded the RS particle clearance from the rumen (Win et al., 2021).

In this feeding experiment, body weight gain (81.70 vs $76.68 \mathrm{~kg})$ and average daily gain $(575.35 \mathrm{vs}$ $540.00 \mathrm{~g} /$ day) were greater $(\mathrm{P}>0.05)$ for $\mathrm{CC} 1$ bulls than that for $\mathrm{CC} 2$ bulls. Average daily gain (ADG) attained in the current research was greater than the result of Kyawt et al. (2020) and lower than findings of (Dung et al., 2013; Hnin Hnin Htwe et al., 2019; Win et al., 2021). The feed conversion ratio (FCR) of two commercial concentrates did not differ between treatment bulls in the values of 12.21 for $\mathrm{CC} 1$ and 12.58 for $\mathrm{CC} 2(\mathrm{P}>0.05)$. Observed FCR values in this research were larger than values of Hnin Hnin Htwe et al., 2019, and Win et al. (2021). These variations can be attributed by different feed resources applied in the respective experiments such as types of basal diets, intensity of digestibility, ingredients variation in concentrate and breeds of animals. 
Table 1 Chemical composition of experimental feedstuffs (\%)

\begin{tabular}{|l|l|l|r|}
\hline Feedstuffs & DM & OM & \multicolumn{1}{l|}{ CP } \\
\hline Rice straw & 92.61 & 80.63 & 3.69 \\
\hline Commercial Concentrate 1 & 90.44 & 89.40 & 19.43 \\
\hline Commercial concentrate 2 & 91.15 & 88.55 & 20.93 \\
\hline
\end{tabular}

DM: dry matter, OM: organic matter, CP: crude protein

Table 2. DM intake, growth characteristics of young Pyar Sein bulls fed rice straw \& commercial conc.

\begin{tabular}{|l|c|l|l|}
\hline Items & concentrate 1 & concentrate 2 & P-value \\
\hline Initial body wt. $(\mathrm{kg})$ & 259.63 & 256.72 & \\
\hline Final body wt. $(\mathrm{kg})$ & 341.33 & 333.40 & \\
\hline Weight gain (kg) & 81.70 & 76.68 & $\mathrm{NS}$ \\
\hline Average daily gain (ADG) (g/day) & 575.35 & 540.00 & $\mathrm{NS}$ \\
\hline DM intake of RS (kg) & 4.25 & 4.15 & $\mathrm{NS}$ \\
\hline Total DM intake (kg) & 6.96 & 6.73 & $\mathrm{NS}$ \\
\hline DM intake of RS (\% BW) & 1.35 & 1.36 & $\mathrm{NS}$ \\
\hline Total DM intake (\% of BW) & 2.21 & 2.21 & $\mathrm{NS}$ \\
\hline Feed conversion ratio (FCR) & 12.21 & 12.58 & $\mathrm{NS}$ \\
\hline Wither height & & & \\
\hline Initial height $(\mathrm{cm})$ & 118.75 & 120.16 & \\
\hline Final height $(\mathrm{cm})$ & 124.28 & 125.24 & \\
\hline Increased height $(\mathrm{cm})$ & 5.53 & 5.08 & $\mathrm{NS}$ \\
\hline Rump height & & & \\
\hline Initial height $(\mathrm{cm})$ & 122.50 & 124.73 & \\
\hline Final height $(\mathrm{cm})$ & 128.55 & 128.56 & \\
\hline Increased height $(\mathrm{cm})$ & 6.05 & 3.83 & $\mathrm{NS}$ \\
\hline
\end{tabular}

Commercial concentrate 1: soybean meal, sunflower meal, peanut cake, sesame cake, cotton cake, coconut cake, palm kernel cake, rapeseed cake, wheat bran, rice bran, corn, broken rice, molasses, salt, vitamins, dicalcium phosphate, amino acid, minerals, etc. Commercial concentrate 2: palm kernel meal, corn, wheat bran, rice bran, green bean shell, dried distillers grains (DDGS). BW: body weight, NS: non-significance

Table 3 Mean values of feedstuffs and feeding cost

\begin{tabular}{|l|l|l|l|l|l|l|l|}
\hline Items & $\begin{array}{l}\text { Crude protein } \\
\text { CP }(\%)\end{array}$ & $\begin{array}{l}\text { Price of feed } \\
(/ \mathrm{kg})\end{array}$ & $\begin{array}{l}\text { Conc. given } \\
(\mathrm{kg} / \mathrm{head} / \mathrm{day})\end{array}$ & $\begin{array}{l}\text { Conc. cost } \\
(/ \mathrm{head} / \mathrm{day})\end{array}$ & $\begin{array}{l}\text { Rice straw } \\
(\mathrm{kg} / \mathrm{head} / \mathrm{day})\end{array}$ & $\begin{array}{l}\text { Rice straw cost } \\
(/ \mathrm{head} / \mathrm{day})\end{array}$ & $\begin{array}{l}\text { Total feed cost } \\
(/ \mathrm{head} / \mathrm{day})\end{array}$ \\
\hline Rice straw & 3.69 & 107.00 & - & - & - & - & - \\
\hline $\begin{array}{l}\text { Commercial } \\
\text { concentrate } 1\end{array}$ & 19.43 & 531.99 & 2.71 & $1442.41^{\mathrm{a}}$ & 4.59 & 491.48 & $1933.89^{\mathrm{a}}$ \\
\hline $\begin{array}{l}\text { Commercial } \\
\text { concentrate 2 }\end{array}$ & 20.93 & 500.82 & 2.58 & $1293.31^{\mathrm{a}}$ & 4.48 & 479.15 & $1772.45^{\mathrm{a}}$ \\
\hline
\end{tabular}

Price in MMK

Commercial concentrate 1: soybean meal, sunflower meal, peanut cake, sesame cake, cotton cake, coconut cake, palm kernel cake, rapeseed cake, wheat bran, rice bran, corn, broken rice, molasses, salt, vitamins, dicalcium phosphate, amino acid, minerals, etc.

Commercial concentrate 2: palm kernel meal, corn, wheat bran, rice bran, green bean shell, dried distillers grains (DDGS).

Means $(n=6)^{a}$ : Means with the same superscript in the same column is not significantly different $(P<0.05)$.

The wither height and rump height of young bulls is presented in Table 2. Average daily weight gain and body size is commonly evaluated by increased of hearth girth and body length and has a positive correlation with hip height (Puspitaningrum, 2009). There was no significantly different in the structural growth of wither height $(5.53$ vs $5.08 \mathrm{~cm})$ and rump height $(6.05$ vs $3.83 \mathrm{~cm})$ of local Pyar Sein bulls between CC1 and CC2 groups for five months $(\mathrm{P}>0.05)$, although wither height and rump height for $\mathrm{CC} 1$ grouped bulls were relatively greater than that for $\mathrm{CC} 2$ grouped bulls. The increased lengths in wither height and rump height for young bulls in this experiment did not far differ compared to the occurred lengths of Holstein Friesian crossbred steers (Hnin Hnin Htwe et al., 2019). The current study showed that two commercial concentrates consisted of different ingredients did not clearly affect voluntary DMI of RS because the CP contents of these complete feed are nearly same which resulted or created to similar ruminal functions, improved digestibility and growth performance of local young bulls. Therefore, Doyle et al. (1986) reported that without supplementing of any other nutrient resources, RS feeding alone will lead to poorer performance of the animal because RS cannot consist of enough sugar, amino acids and minerals for efficient microbial growth.

From the point of economic evaluation, prices of animal feed were analyzed based on the current market from two local feed shops and paddy farmers. Mean prices for CC1, CC2 and RS were 531.9MMK/kg, 
$500.8 \mathrm{MMK} / \mathrm{kg}$ and $107.0 \mathrm{MMK} / \mathrm{kg}$, respectively. The daily feeding costs of concentrate, rice straw and total feeding cost for two grouped bulls are displayed in Table 3. The greater total feeding cost per day for CC1 group than cost for CC2 group was mostly generated from high price of CC1, however, total feeding costs for two grouped bulls were not differed $(\mathrm{P}>0.05)$. Therefore, this feeding trial found that the use of commercial concentrate 2 would favour and save the money for the small-scale farmers for increasing body weight of local young bulls and reduction of agricultural crop residue. The feeding of rice straw to ruminants by supplementing method can both contribute to the food bank and eliminate environmental problems that arise from the current practice of burning rice straw in the fields.

\section{Conclusion}

Rice straw applied as primary roughage source supplemented with two commercial concentrates did not find different effects on DMI, ADG, FCR, wither height and rump height of young Pyar Sein bulls. This study recommends that commercial concentrates containing CP20\% with $1 \%$ live body weight allowance is suitable for local young bulls fed rice straw as a basal diet for the dry season in Myanmar.

\section{Conflict of Interest}

All authors declared no competing interests.

\section{References}

1) AOAC. 1990. Official methods of analysis. 15th ed. Arlington (VA): Association of Official Analytical Chemists.

2) Bakshi MPS and Wadhwa M. 2017. Utilization of rice-straw as livestock feed. Indian Farming. 67(07): 27 29.

3) Cho AS, Ueda K, Kondo S. 2012. Evaluation of associative effects on ruminal digestion kinetics between rice straw and protein supplements. Animal Science and Agriculture Hokkaido, 54: 47-52.

4) Devendra C. 1997. Crop residues for feeding animals in Asia: Technology development and adoption in crop/livestock systems. In: Crop Residuals in Sustainable Mixed Crop/Livestock Farming System (Renard, C. eds). pp. 240-261. CAB International; Wallingford, UK.

5) Doyle PT, Devendra C, Pearce GR. 1986. Rice straw as a feed for ruminants. International Development Program of Australian Universities and Colleges (IDP), Canberra, Australia.

6) FAOSTAT, 2018. Statistics Division. Food and Agriculture Organization of the United States.

7) Fike GD, Simmis DD, Cochran RC, Vanzant ES, Kutil GL, Brandt RT Jr. 1995. Protein supplementation of ammonia treated wheat straw: Effect on performance and forage utilization of beef cattle. Journal of Animal Science. 73: 1595-1601.

8) Ghorbani B, Yansari AT, Sayyadi AJ. 2018. Effects of sesame meal on intake, digestibility, rumen characteristics, chewing activity and growth of lambs. South African Journal of Animal Science. 48: 151-161.

9) Htwe HH, Htan HP, Thang HH, Thang M, Thnag BH, Htan HH, Thang EK, Htike AS, Htet NL, Htet MM. 2019. Comparison of feed intake, weight gain and body growth rate in crossbred steers fed diets based napier grass and napier grass silage. Graduation Thesis. Group 7, 2019.

10) Dung DV, Ba NX, Van NH, Phung LD, Ngoan LD, Cuong VC, Yao W. 2013. Practice on improving fattening local cattle production in Vietnam by increasing crude protein level in concentrate and concentrate level. Tropical Animal Health and Production 45(7):1619-26.

11) GNLM. 2020. Exports of cattle, animal products down by $\$ 222.5 \mathrm{mln}$ in current FY. https://www.gnlm.com.mm/exports-of-cattle-animal-products-down-by-222-5-mln- in- current-fy

12) Huyen, NT, Wanapt M, Navanukraw C. 2012. Effect of mulberry leaf pellet (MUP) supplementation on rumen fermentation and nutrient digestibility in beef cattle fed on rice straw based diets. Animal Feed Science and Technology. 175: 8-15.

13) Kempton TJ, Nolan VV, Leng RA. 1977. Principles for the use of non-protein nitrogen and by-pass protein in diets for ruminants. World Animal Review. 22: 18-24

14) Kyawt YY, Win KS Mu KS, Aung A, Aung M. 2020. Feeding pineapple waste silage as roughage source improved the nutrient intakes, energy status and growth performances of growing Myanmar local cattle. Journal of advanced veterinary and animal research. 7(3):436-441.

15) Lal R. 2005. World crop residues production and implications of its use as a biofuel. Environ. Int. 31, 575584. https://doi.org/10.1016/j.envint.2004.09.005.

16) Liu JX, Yao J, Yan B, Yu JQ, Shi ZQ. 2001. Effects of mulberry leaves to replace rapeseed meal on performance of shee feeding on ammoniated rice straw diet. Small Ruminant Research. 39: 131-136.

17) McCollum FT and Glayean ML. 1985. Influence of cottonseed meal supplementation on voluntary intake, rumen fermentation and rate of passage of prairie hay in beef steers. Journal of Animal Science. 60: $570-577$. 
18) Minson DJ.1985. Fiber as a limit to tropical animal production. Proceeding of $3^{\text {rd }}$ Asian-Australasian Association of Animal Production (AAAP) Congress. Seoul. Vol. 1, pp: 108-119.

19) Moran JB, Satoto KB, Dawson JE.1983. The utilization of rice straw fed to zebu cattle and swamp buffalo as influenced by alkali treatment and Leucaena supplementation. Australian Journal Agricultural Research. 34: 73-84.

20) Myanmar Statistical Year Book. 2019. Central Statistical Organization. Ministry of Planning and Finance. The Government of the Republic of the Union of Myanmar.

21) NRC. 2000. National Research Council. Nutrient requirements of beef cattle. $7^{\text {th }}$ revised edition, National Academies Press, Washington, DC.

22) Puspitaningrom D. 2009. Estimation of live weight on body size dimension of Brahman crossbred cattle. Research report. Faculty of Animal Husbandry, Brawijaya University, Malang.

23) Snedecor GW, Cochran WG, 1994. Statistical methods. 8th ed. Ames: Iowa State University Press.p593.

24) Soe TM, Mu KS, Ngwe T. 2007. Effects of groundnut, black gram and green gram residues on intake, digestibility and nitrogen utilization as supplement in goat fed on rice straw. Myanmar Veterinary Journal, 9-18.

25) Sommart, K. 1998. The use of cassava in ruminant diets based on low quality roughages. Ph.D Thesis in Ruminant Nutrition. University of Newcastle Upon Tyne, Newcastle, UK.

26) Takahira Y, Kanaya C, Yoshino E, Kon H, Maruyama T, Kasuya K. 2011. Effects of feeding whole-crop rice silage with reduced $b$-carotene content on various characteristics of Japanese Black steers. Japan Journal of Grassland Science 56, 245-252. (In Japanese)

27) Win KS, Aung Y, Kyaw ZT, Lay KK, Oo HL. 2021. Effect of two different types of concentrate on dry matter intake, body weight gain and body growth of Pyar Sein calves fed black gram crop residue. Journal of Livestock Science. 12: 65-70.

28) Win KS, Ueda K, Kondo S. 2021. Effects of soybean meal supplementation on ruminal kinetics of feed particle size reduction and passage in dairy cows fed rice straw. Animal Science Journal. 92 (1): 1-9. 